Too much money

has been spent

on lackluster

money-making

goals, such as

certain viral and

fungal

resistances. relatively low in commercial attractiveness. Conversely, commercially juicy targets have not yet yielded to the science. Conference attendees argued that probably too much money has been spent on lackluster money-making goals, such as certain viral and fungal resistances. On the other hand, objectives with wide commercial appeal, like improvements in fibers and flowering, were starved for attention. Features difficult to address with biotechnology were not neglected just because of genetic complexity, however. Of the finite number of agbiotech laboratories, most appeared preoccupied with moderate-payoff projects that had some tangible scientific result. Preoccupation with such projects could preclude research on subjects of higher commercial potential, a perverse concept given the number of for-profit companies represented at the conference.

Individual data points became stories all their own. Conferees agreed that improvements in photosynthetic efficiency had almost twice the commercial potential of other traits. Yet both public and private research funding for rubisco-the large, and notoriously inefficient, enzyme responsible for carbon fixation-was anemic for no good reason. In contrast, despite the hoopla about making money from herbicide resistances, with almost 500 field trials involving herbicide resistances underway, skeptics abounded. Multiple herbicide resistances in individual crops may become commonplace, and no single herbicide resistance could emerge as valuable. An exception to this rule might be resistance to Roundup (glyphosate), a herbicide made by Monsanto (St. Louis, MO). In coming years, the scrutiny of consumers or environmentalists could intensify as the popular press increasingly features this trait. Environmental activism, in fact, contributed to the low commercial ranking of herbicide resistance.

Participants were pleased by the continued emphasis on genetic markers (Mk), including randomfragment-length polymorphism (RFLP). These technologies are the first tangible contributions of molecular biology to plant breeding. Conferees lamented that the significance of RFLP had been underplayed and that the technology had become something of a stepchild to plant transformation. However, over the next decade, genetic markers will be extended to more than 20 crops and will enable breeders to follow traits through individual crosses, as well as breeding cycles. Application of genetic markers might reduce the 10-15 year breeding cycles by 2-3 years.

III

George Kidd is president of management consultants Kidd \& Company (Shorewood, WI).

\title{
Going public boosts executive compensation
}

NEW YORK-It pays for U.S. biotech companies to go public, at least as far as executive compensation goes. Indeed, biotech executives at the smaller U.S. public companies-a ranking that excludes the 20 public companies with the biggest market capitalizations-currently make annual salaries of $\$ 132,000$ and get bonuses of $\$ 30,200$, on average. For their part, biotech executives at private U.S. companies lag behind, typically collecting annual salaries of $\$ 97,600$, with bonuses of $\$ 16,300$ (Table 1).

So reports a survey by J. Robert Scott (Boston, MA) and Coopers \& Lybrand (New York) entitled 1994 Leadership in Biotechnology, which includes responses from biotech executives at 65 smaller public firms and 65 private firms. Smaller public firms were 9.5 years old and had annual revenues of $\$ 3.3$ million, on average, while private firms were 9 years old, with annual revenues of $\$ 4$ million.

Chief executive officers (CEOs), of course, make the biggest killing, at both smaller public companies and private companies. CEOs at smaller public companies typically get salaries of $\$ 198,000$ and bonuses of $\$ 64,700$. Private-company CEOs, on the other hand, generally take home $\$ 129,000$, with bonuses of $\$ 31,400$. Vice presidents of research and development (VPs of $R \& D$ ) are the next biggest bread winners, in both smaller public firms and private firms.

CEOs are also the biggest equity owners, though private-company CEOs lead the way in this area of compensation. In private companies, CEOs generally own 8.7 percent of a firm's equity, while, in smaller public companies, smaller public companies,
CEOs typically hold a 2.7 per-
TABLE 1.

Executive compensation.

\begin{tabular}{|c|c|c|c|c|}
\hline \multirow[b]{2}{*}{ Executive } & \multirow[b]{2}{*}{ Company } & \multicolumn{2}{|c|}{ SALARY } & BONUS \\
\hline & & $\begin{array}{l}\text { Current } \\
\text { Year }\end{array}$ & $\begin{array}{c}\text { Change From } \\
\text { Previous Year }(\%)\end{array}$ & $\begin{array}{r}\text { Current } \\
\text { Year }\end{array}$ \\
\hline \multirow[t]{2}{*}{ Chief Executive Officer } & Private & 129,000 & 8 & 30,600 \\
\hline & Smaller public & 198,000 & 11 & 64,700 \\
\hline \multirow{2}{*}{$\begin{array}{l}\text { VP of Research } \\
\text { \& Development }\end{array}$} & Private & 101,000 & 5 & 12,900 \\
\hline & Smaller public & 128,000 & 8 & 23,700 \\
\hline \multirow[t]{2}{*}{ VP of Operations } & Private & 87,000 & 13 & 7,800 \\
\hline & Smaller public & 109,000 & 9 & 14,300 \\
\hline \multirow[t]{2}{*}{ Chief Financial Officer } & Private & 89,000 & 11 & 11,700 \\
\hline & Smaller public & 110,000 & 12 & 21,500 \\
\hline VP of Business & Private & 82,000 & 5 & 17,900 \\
\hline Development & Smaller public & 115,000 & 9 & 27,000 \\
\hline \multirow[t]{2}{*}{ Average } & Private & 97,600 & 8.4 & 16,000 \\
\hline & Smaller public & 132,000 & 9.8 & 30,200 \\
\hline $\begin{array}{l}1994 \text { Leade } \\
\text { Coopers \& }\end{array}$ & ership in Biotech & $\begin{array}{l}\text { logy by } \mathrm{J} \\
\text { k). }\end{array}$ & lobert Scott (Boston, & MA) and \\
\hline
\end{tabular}
cent share of a firm's stock. VPs of R\&D are the runners up in this compensation category, too, with private-company VPs of R\&D owning 3.7 percent of a firm's equity, on average, and their smallerpublic-company counterparts holding a 0.7 percent share of a firm's stock. CEOs and VPs of R\&D typically own the biggest stakes in their companies because these executives are most often the company founders.

-Mike Ginsberg 